\title{
ANTIBROWNING AND ANTIMICROBIAL EFFECTS OF ONION ESSENTIAL OIL TO PRESERVE THE QUALITY OF CUT POTATOES
}

\author{
F.J. Vazquez-Armenta a, J.F. Ayala-Zavala ${ }^{a}$, G.I. Olivas ${ }^{\text {b }}$, F.J. Molina-Corral ${ }^{b}$ \\ and B.A. SILVA-ESPINOZA* \\ ${ }^{a}$ Centro de Investigación en Alimentación y Desarrollo, A.C. Coordinacion de Tecnologia de Alimentos de Origen \\ Vegetal. Carretera a la Victoria Km 0.6, La Victoria. Hermosillo, Sonora (83000). Mexico. \\ ${ }^{\mathrm{b}}$ Centro de Investigacion en Alimentacion y Desarrollo, A.C., Unidad Cuauhtemoc, Av. Rio Conchos S/N Parque \\ Industrial, Apartado Postal 781. Cuauhtemoc (31570), Chihuahua. Mexico.
}

(Submitted: 2 May 2013; accepted: 22 July 2013)

This study evaluated the effect of onion essential oil (OEO) $\left(0,0.5,2.5\right.$, and $\left.5 \mathrm{mg} \mathrm{ml}^{-1}\right)$ on microbial growth, browning decay, and sensorial appealing of cut potatoes stored for 15 days at $4{ }^{\circ} \mathrm{C}$. Dipropyl disulphide and dipropyl trisulphide were the main constituents identified in OEO, and its application at a dose of $0.5 \mathrm{mg} \mathrm{m}^{-1}$ was the most effective to prevent browning ( $38.5 \%$ inhibition respect to control) during storage, inhibiting PPO activity ( $39 \%$ respect to control) after the treatment. The higher the added OEO concentration the lower microbial growth of the treated product was, achieving a reduction of $1.27 \log \mathrm{CFU} \mathrm{g}{ }^{-1}$ for the $5 \mathrm{mg} \mathrm{ml}^{-1}$ treatment. The odour and flavour appealing of cut potatoes were well received by the panelists after 10 days of storage. Therefore, the use of OEO in cut potatoes has a potential as antimicrobial and antibrowning agent.

Keywords: sulphur compounds, enzyme inhibition, food quality

Potatoes (Solanum tuberosum L.) are considered to have commercial interest in the fresh-cut market (Montouto-Graña et al., 2012). However, cut potatoes are highly perishable, since their quality is severely affected by the processing operations, such as peeling and cutting (Montero-Calderón \& Cerdas-Araya, 2009). During processing cells are damaged and their intercellular content is released, liberating sugars and phenolic compounds, which become a substrate for enzymes and a source of nutrients for spoilage microorganisms (ERTURK \& Picha, 2006). For this reason, enzymatic browning and microbial spoilage are considered as the main causes of quality loss of cut potatoes (CABEZAS-SERRANO et al., 2009).

Polyphenol oxidase (PPO) forms compounds that are then transformed by non-enzymatic reactions into melanins, which are dark pigments responsible for a less attractive appearance and the loss of nutritional quality of potatoes (Cornacchia et al., 2011). On the other hand, microbial spoilage is caused by the proliferation of microorganisms limiting the safety and shelf-life of cut potatoes (BENKEBLIA, 2004). Various techniques have been applied to maintain the quality attributes of cut vegetables, such as the addition of sulphites (SGROPPO et al., 2010). However, consumers demand products with no synthetic chemicals (PonCE et al., 2003). In this context, onion (Allium cepa) essential oil (OEO) has been of great interest in the food industry due to its potential as antimicrobial and antibrowning additive (Hosoda et al., 2003; BENKEBLIA, 2004).

\footnotetext{
* To whom correspondence should be addressed.

Phone: +52 (662) 289-24-00 ext 202; fax: +52 (662) 280-04-22; e-mail: bsilva@ciad.mx
} 
The OEO consists of a mixture of alk(-en)yl sulphides and higher sulphides (SINHA et al., 1992) that possess antimicrobial properties against a wide range of bacteria (BENKEBLIA, 2004). In addition, onion sulphur compounds inhibited the enzymatic browning in vegetables (LEE et al., 2007). It is believed that the mode of action of sulphur compounds, like those found in OEO, involves the formation of disulphide bonds with sulphured amino acids of enzymes (like PPO and vital microbial enzymes), leading to a partial or complete loss of enzymatic activity (KyUnG \& LEE, 2001). The present work states that the application of OEO inhibits the enzymatic browning and microbial decay of cut potatoes.

\section{Materials and methods}

\subsection{Identification of compounds in $O E O$}

Identification of sulphur constituents of OEO (Sigma-Aldrich, catalogue number: W281719 Toluca, Mexico) was done as described previously for other oils (AyAlA-Zavala \& GonzÁlezAguilar, 2010). The identification of the compounds was based on the comparison of their mass spectra with those of the Saturn library and NIST 98 library data of the GC-MS system.

\subsection{Processing and oil treatment of cut potato}

Potatoes were sanitized for $2 \mathrm{~min}$ in chlorinated water (200 ppm) and gently dried by hand, manually peeled with a stainless steel knife, and cut into $7 \mathrm{~mm}$ thick slices with a commercial slicing machine. Potato slices were immersed for $2 \mathrm{~min}$ in emulsions of OEO in water $(0.5$, $2.5,5 \mathrm{mg} \mathrm{ml}^{-1}$ ), prepared mechanically using a homogenizer (Ultraturrax t25, IKA, Mexico) and Tween 20 as surfactant $\left(2 \mathrm{ml} \mathrm{l}^{-1}\right)$. Slices treated with sterile water containing no OEO were used as controls. The excess of emulsion was drained; thereafter, 3 potato slices per treatment were placed in a $300 \mathrm{ml}$ polystyrene tray covered with a lid of the same material. Forty trays per treatment were stored at $4 \pm 1{ }^{\circ} \mathrm{C}$, samples were taken throughout 15 days of storage to perform the microbial, biochemical, and sensorial analyses.

\subsection{OEO compounds in cut potatoes}

Sulphur compounds analysis in potato slices treated with OEO was carried out with the SPME procedure as described for the oil analysis, using $10 \mathrm{~g}$ of homogenized sample $(\mathrm{n}=3)$. The volatile compounds previously identified by GC-MS were detected in the samples and the relative quantification was achieved by integrating the area under the curve of each compound.

\subsection{Browning index}

Samples treated with OEO were evaluated subjectively throughout 15 days of storage on a 1-5 scale according to the browning condition of the product, where 1: none, 2: traces; 3 : moderate, 4: severe, and 5: extremely severe. Results were expressed as browning index (BI), using the formula: $B I=(1 n+2 n+3 n+4 n+5 n) \times N^{-1}$, where $n$ is the number of samples ranked at any level of the hedonic scale and $N$ is the total number of samples analyzed, for every sampling day. 


\subsection{Polyphenol oxidase activity}

Ten $\mathrm{g}$ of potato were homogenized in $20 \mathrm{ml}$ of $0.1 \mathrm{M}$ phosphate buffer ( $\mathrm{pH}$ : 7) with $1 \mathrm{~g}$ of polyvinylpolypyrrolidone, and centrifuged $\left(12000 \times g\right.$, $15 \mathrm{~min}$ at $4{ }^{\circ} \mathrm{C}$ ). PPO activity was determined in the supernatant by measuring the absorbance increase at $416 \mathrm{~nm}$ over a period of $30 \mathrm{~s}$ at $25^{\circ} \mathrm{C}$ in a multi-mode microplate reader (FLUOstar Omega, BMG LABTECH's, USA). The reaction mixture contained $30 \mu \mathrm{l}$ of $0.024 \mathrm{M}$ catechol solution, $220 \mu \mathrm{l}$ of phosphate buffer, and $50 \mu \mathrm{l}$ of PPO extract. Results were expressed as units of enzymatic activity per mg of protein (UE $\left.\mathrm{mg}^{-1}\right)$ (CHINWANG et al., 2011).

\subsection{Microbiological analysis}

Cut potatoes were diluted (1:9) in a solution containing $0.001 \mathrm{~g} \mathrm{ml}^{-1}$ of peptone and homogenized for $1 \mathrm{~min}$. Subsequently, 10-fold dilutions were also made in this diluent. Aerobic plate count, yeast and mould, and total coliform analyses were performed according to the U.S. FDA Bacteriological Analytical Manual methodology. Results were expressed as $\log$ colony forming units per gram of potato $\left(\log _{10} \mathrm{CFU} \mathrm{g}^{-1}\right)$.

\subsection{Sensory acceptability}

The acceptability of odour and flavour of potatoes treated with OEO was evaluated at 0 and 10 days of storage at $4{ }^{\circ} \mathrm{C}$ as described previously (Ayala-Zavala \& González-Aguilar, 2010). Sensory evaluation was performed by a consumer test using 30 untrained panelists. The acceptance of odour and flavour was evaluated on a 5-point hedonic scale, where 1: dislike extremely, 2: dislike moderately; 3: neither like nor dislike; 4: like moderately, and 5: like extremely. The results were expressed as acceptability of odour and flavour.

\subsection{Statistical analysis}

A factorial design experiment was used: oil treatment and storage time were used for the evaluated responses. Data were subjected to ANOVA and mean comparisons were done using Tukey-Kramer multiple comparison test at the 5\% level.

\section{Results and discussion}

\subsection{Identification of OEO compounds}

The main constituents of OEO were dipropyl disulphide $(60.4 \% \mathrm{w} / \mathrm{w})$, dipropyl trisulphide (17.1\%), methyl propyl disulphide (7.05\%), dimethyl trisulphide (1.14\%), dimethyl tetrasulphide $(0.46 \%)$, and isopropyl disulphide (0.31\%) (Fig. 1). Hosoda and co-workers (2003) reported dipropyl trisulphide (21.92\%), dipropyl disulphide (21.31\%) and methyl propyl trisulphide (14.98\%) as major components of OEO. Similar results were obtained by SINHA and co-workers (1992) who reported that dipropyl trisulphide (23.07\%), dipropyl disulphide (22.48\%), methyl propyl trisulphide (14.88\%), 1-propenyl propyl disulphide (7.24\%), and 1-propenyl propyl trisulphide (7.11\%) were the major constituents. Organosulphur compounds, such as mono-, di-, and trisulphide, have been reported to affect enzymatic reactions, like those responsible for microbial growth and browning in vegetables (Pérez-Gilabert \& García-Carmona, 2001; Kim et al., 2004). 


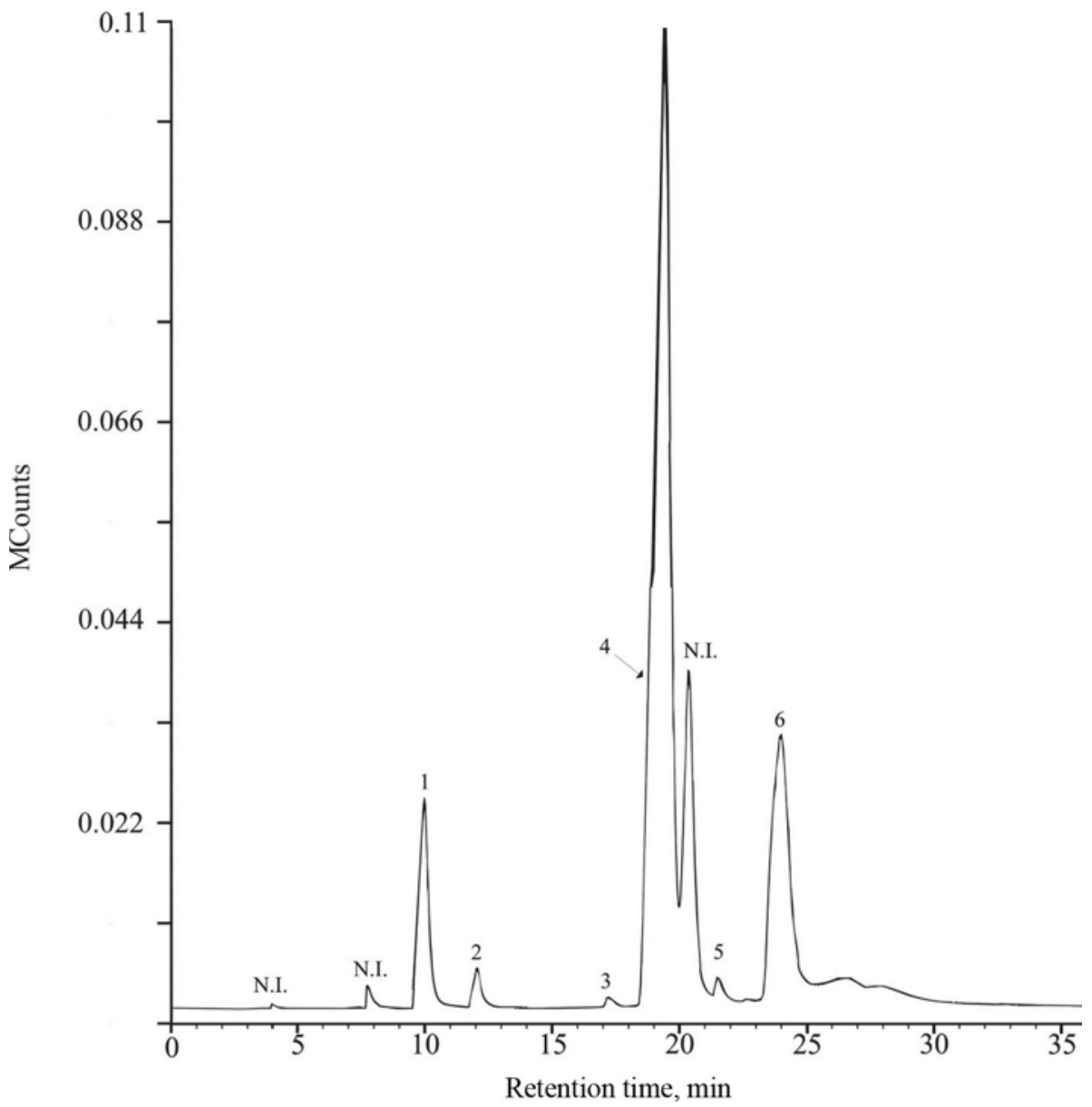

Fig. 1. Volatile profile of OEO. The content of each identified compound in area\%: 1: Methyl propyl disulphide $7.05 \%$; 2: dimethyl trisulfide $1.14 \%$; 3: Isopropyl disulphide $0,31 \%$; dipropyl disulphide $60.4 \%$; : dimethyl tetrasulfide $0.46 \%$; 6 : dipropyl trisulfide $0.46 \%$; N.I.: not identified

\subsection{OEO compounds in cut potatoes}

The number of compound identified varied with the applied dose: at $5 \mathrm{mg} \mathrm{ml}^{-1}$ (methyl propyl disulphide, isopropyl disulphide, dipropyl disulphide, dimethyl tetrasulphide and dipropyl tetrasulphide), at $2.5 \mathrm{mg} \mathrm{ml}^{-1}$ (methyl propyl disulphide, dipropyl disulphide, dimethyl tetrasulphide and dipropyl trisulphide), and at $0.5 \mathrm{mg} \mathrm{ml}^{-1}$ (dipropyl disulphide and dipropyl trisulphide). The content of these compounds decreased with the storage time, this pattern is shown in Fig. 2 for dipropyl disulphide and dipropyl trisulphide. Dipropyl disulphide was detected up to day 10 for treatments 2.5 and $5 \mathrm{mg} \mathrm{ml}^{-1}$, while for $0.5 \mathrm{mg} \mathrm{ml}^{-1}$ it was detected until day 5. Dipropyl trisulphide was present until day 5 on the potato surfaces treated with 2.5 and $5 \mathrm{mg} \mathrm{ml}^{-1}$, while in $0.5 \mathrm{mg} \mathrm{ml}^{-1}$ it was detected only on the first day. Considering that the identified compounds are responsible for the active properties of OEO, and that their presence in the potato tissues decreased during storage, it is evident that this situation would affect the efficacy of the treatments. 


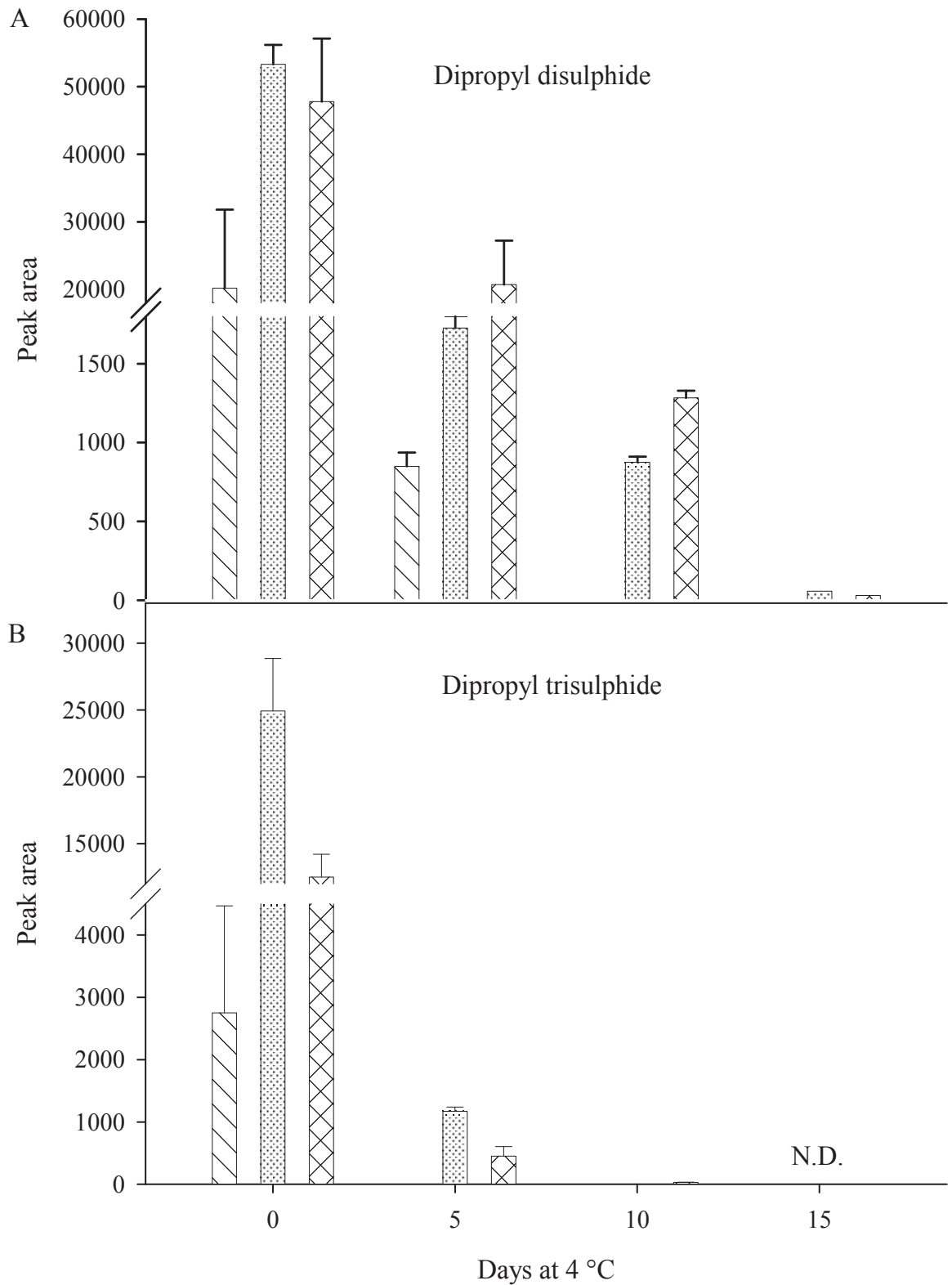

Fig. 2. Changes of dipropyl disulphide (A) and dipropyl trisulphide (B) on the surface of potato slices treated with

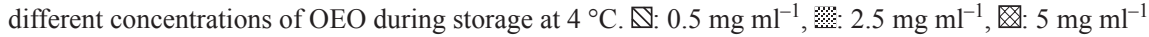

\subsection{Browning index and PPO activity}

The most effective treatment for retarding the browning development in cut potato surfaces was $5 \mathrm{mg} \mathrm{ml}^{-1}$ of OEO with a decrease of $37 \%$ compared to control (Fig. 3A). However, at the end of the storage time no differences $(\mathrm{P}<0.05)$ were found among $2.5,0.5$, and $0 \mathrm{mg} \mathrm{ml}^{-1}$. 
Immediately after the oil treatment with 5 and $2.5 \mathrm{mg} \mathrm{ml}^{-1}(\mathrm{P}>0.05)$ a PPO activity decrement $\approx 39 \%$ was observed compared to the control samples $(\mathrm{P}<0.05)$ (Fig. 3B). The potato slices treated with $5 \mathrm{mg} \mathrm{ml}^{-1}$ of OEO showed less PPO activity followed by $2.5 \mathrm{mg} \mathrm{ml}^{-1}$ up to day $10(\mathrm{P}<0.05)$, no major enzymatic inhibition was caused by the lowest oil concentration. However, at $15^{\text {th }}$ day of storage no differences $(\mathrm{P}>0.05)$ were found among treatments. A negative correlation between PPO activity $(\mathrm{r}=-0.6669 ; \mathrm{P}=0.0048)$ and $\mathrm{BI}(\mathrm{r}=-0.5343$; $\mathrm{P}=0.0330$ ) against sulphur compounds (dipropyl disulphide and dipropyl trisulphide) remnant in potato tissues was observed; indicating that the loss of active volatiles triggered the rate of browning decay of cut potatoes, and the loss of efficacy of these treatments with storage time.



Fig. 3. Browning index (A) and PPO activity (B) of cut potatoes treated whit OEO during storage at $4{ }^{\circ} \mathrm{C}$. -—: $0 \mathrm{mg} \mathrm{ml}^{-1},-\mathrm{O}^{-}: 0.5 \mathrm{mg} \mathrm{ml}^{-1},-\nabla: 2.5 \mathrm{mg} \mathrm{ml}^{-1},-\longleftarrow: 5 \mathrm{mg} \mathrm{ml}^{-1}$. Scale according to the browning condition of the product: 1 : none, 2: traces; 3 : moderate, 4 : severe; and 5: extremely severe. The horizontal segmented line represents the limit of acceptability. * Initial value of the evaluated response 
A previous study has clearly demonstrated that sulphur compounds can act as a slowbinding competitive inhibitor of mushroom tyrosinase (PÉREZ-GilaberT \& GarCíA-CARMONA, 2001). Similarly, STEVEN and co-workers (1981) proposed that dimethyl disulphide reacts with trypsin and papain by a disulphide exchange reaction, thus forming inactive complexes. This model serves to illustrate mechanisms by which some sulphides are capable of modulating enzymatic reactions. HosodA and co-workers (2003) showed the effect of 0.05 and $0.2 \%$ of OEO as an antibrowning treatment in shredded lettuce, observing 20 and $70.4 \%$ of browning inhibition, respectively. The treatment of potato slices with sodium bisulphite $0.25 \%$ and ascorbic acid $1.25 \%+$ citric acid $1.25 \%$ in combination with controlled atmospheres showed no efficacy inhibiting PPO activity during storage (MA et al., 2010).

\subsection{Microbial growth}

The initial count of untreated cut potatoes was $3.38 \log _{10} \mathrm{CFU} \mathrm{g}^{-1}$ and after application of OEO they showed lower counts (Fig. 4): 2.11, 2.74, and $3.16 \log _{10} \mathrm{CFU} \mathrm{g}^{-1}(\mathrm{P}<0.05)$, applying concentrations of $5,2.5$, and $0.5 \mathrm{mg} \mathrm{ml}^{-1}$ of $\mathrm{OEO}$, respectively. The most effective treatment was obtained with $5 \mathrm{mg} \mathrm{ml}^{-1}$, which reduced about 1.27 logarithmic cycles of the initial population. By day 5, there was an increase in the population in all treatments above $4.0 \log _{10}$ CFU g ${ }^{-1}$ and it practically remained unchanged until the end of storage $(\mathrm{P}>0.05)$. No counts of yeasts, moulds, and total coliforms were detected in the analyzed product. A negative correlation between mesophilic aerobic bacteria and sulphur compounds $(\mathrm{r}=-0.8572$; $\mathrm{P}=0.0026$ ) (dipropyl disulphide and dipropyl trisulphide) was observed. The decrease in effectiveness of the treatments in the microbial growth is likely due to the loss of these volatile compounds.

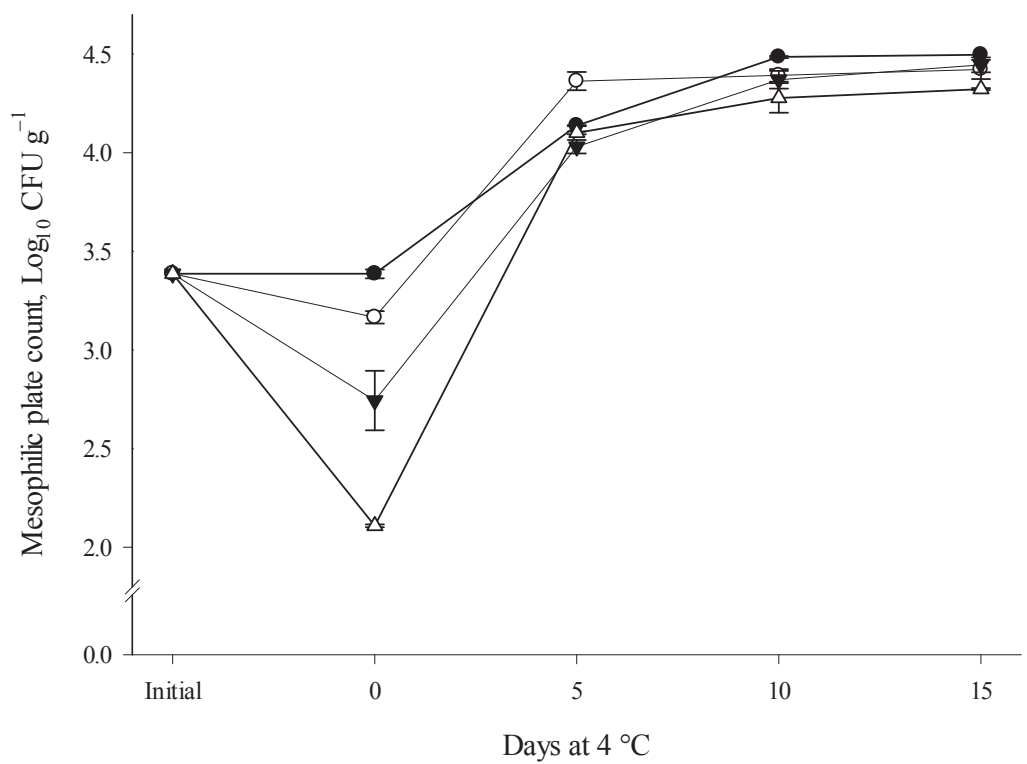

Fig. 4. Effect of bacterial growth on cut potatoes stored at $4{ }^{\circ} \mathrm{C} .--0: 0 \mathrm{mg} \mathrm{ml}^{-1},-\mathrm{O}-: 0.5 \mathrm{mg} \mathrm{ml}^{-1}$, $\neg$ : $2.5 \mathrm{mg} \mathrm{ml}^{-1}, \neg-5: 5 \mathrm{mg} \mathrm{ml}^{-1}$. Different letters express statistically significant difference between treatments $(\mathrm{P} \leq 0.05)$.* Initial value of the evaluated response 
Sulphur compounds may be involved in the inhibition of the activity of bacterial key enzymes through a similar mechanism as observed with PPO (Kyung \& LeE, 2001). The application of $\mathrm{N}$-acetyl-L-cysteine (1\%) solutions combined with modified atmospheres reduced the aerobic population by 1.2 orders of magnitude on cut potatoes (CACACE et al., 2002). ERTURK and Picha (2006) achieved a reduction of $1.7 \mathrm{log}$ in total aerobic bacteria count on potato slices with immersion in sodium hypochlorite solution $(200 \mathrm{ppm})$ for $5 \mathrm{~min}$ at $1{ }^{\circ} \mathrm{C}$. Comparing with the highest reduction observed in our experiment (1.27 log count) the use of a natural extract could be equated in efficacy to the listed references.

\subsection{Sensory acceptability}

The lowest score of odour was received in the potato slices treated with $5 \mathrm{mg} \mathrm{ml}^{-1}$ (dislike moderately-neither like nor dislike), however, its acceptability increased $(\mathrm{P}<0.05)$ after 10 days of storage (neither like nor dislike-like moderately), whereas the other treated samples remained unchanged (Fig. 5). Regarding the acceptability of flavour (Fig. 5B), the panelists' evaluations at day 0 showed a decrease in acceptance (dislike moderately-neither like nor dislike) for the product treated with $5 \mathrm{mg} \mathrm{ml}^{-1}$ with respect to untreated slices and other concentrations. However, at day 10, the slices treated with 2.5 and $5 \mathrm{mg} \mathrm{ml}^{-1}$ received a higher score (like moderately) than the samples control and $0.5 \mathrm{mg} \mathrm{ml}^{-1}$. The major comments from panelists were that the treated produce presented a slight onion seasoned flavour.

Previous study proved that cut tomatoes treated with garlic oil had reduced microbial growth, however, sensorial acceptability was affected negatively, but, when the garlic oil volatiles were encapsulated and applied, there were no differences of odour acceptability of panelists (Ayala-Zavala \& GonzÁlez-Aguilar, 2010). In the case of the present study, the presence of OEO was well accepted when it was present in low concentrations (after ten days of storage).

\section{Conclusions}

The application of OEO was time effective to prevent enzymatic browning and inhibiting PPO activity, OEO treatment $\left(5 \mathrm{mg} \mathrm{ml}^{-1}\right)$ kept the browning index under the limit of acceptability (moderate) for 15 days of storage, and inhibited microbial growth. The sensorial acceptability of odour and flavour was better accepted by panelists upon 10 days of storage, when only a small amount of sulphur compounds on slices was detected. Considering the loss of OEO volatile compounds and activities during storage time, the use of alternative technologies could be used to optimize its antibrowning, antimicrobial, and flavouring properties. In this context, the use of OEO represents a promising alternative as a natural additive for the cut potato production. 


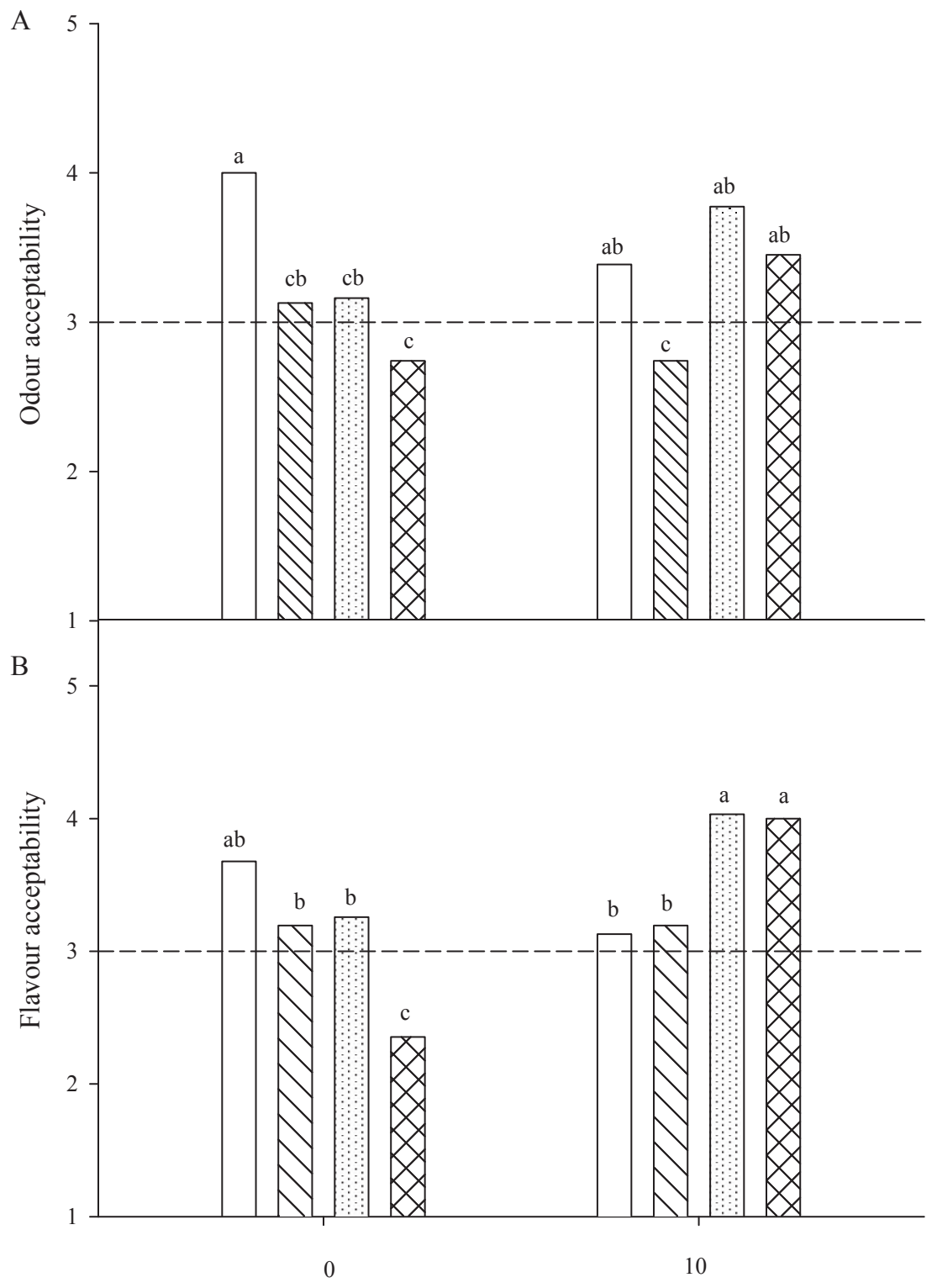

Days at $4{ }^{\circ} \mathrm{C}$

Fig. 5. General acceptability of odour (A) and flavour (B) of potato slices treated with OEO. $\square: 0 \mathrm{mg} \mathrm{ml}^{-1}$, $\mathbb{\mathbb { N }}: 0.5 \mathrm{mg} \mathrm{ml}^{-1}$, $1: 2.5 \mathrm{mg} \mathrm{ml}^{-1}$, 龱: $5 \mathrm{mg} \mathrm{ml}^{-1}$. Hedonic scale used for acceptance test: 1 : dislike extremely; 2: dislike moderately; 3: neither like nor dislike; 4: like moderately; and 5: like extremely. The horizontal segmented line represents the limit of acceptability. Different letters express difference between treatments and days of storage $(\mathrm{P} \leq 0.05)$ 


\section{References}

Ayala-Zavala, J.F. \& González-Aguilar, G.A. (2010): Optimizing the use of garlic oil as antimicrobial agent on fresh-cut tomato through a controlled release system. J. Fd Sci., 75, 398-405.

Benkeblia, N. (2004): Antimicrobial activity of essential oil extracts of various onions (Allium cepa) and garlic (Allium sativum). Lebensm. Wiss. Technol., 37, 263-268.

Cabezas-Serrano, A.B., Amodio, M.L., Cornacchia, R., Rinaldi, R. \& Colelli, G. (2009): Suitability of five different potato cultivars (Solanum tuberosum L.) to be processed as fresh-cut products. Postharvest Biol. Technol., 53, 138-144.

Cacace, J.E., Delaquis, P.J. \& Mazza, G. (2002): Effect of chemical inhibitors and storage temperature on the quality of fresh-cut potatoes. J. Fd Qual., 25, 181-195.

Cornacchia, R., Cabezas-Serrano, A.B., Amodio, M.L. \& Colelli, G. (2011): Suitability of 4 potato cultivars (Solanum tuberosum L.) to be processed as fresh-cut product. Early cultivars. Am. J. Potato Res., 88, 403-412.

Chinwang, U., Siriphanich, J. \& Chairat, R. (2011): Enzymatic browning of fresh-cut galangal (Alpinia siamense K. Schum) and its relationship to oxidative enzymes. J. Jpn. Soc. Hortic. Sci., 80, 103-112.

Erturk, E. \& Picha, D.H. (2006): Microbiological quality of fresh-cut sweet potatoes. Int. J. Fd Sci. Tech., 41, $366-374$.

Hosoda, H., Оhmi, K., Sakaue, K. \& Tanaka, K. (2003): Inhibitory effect of onion oil on browning of shredded lettuce and its active components. J. Jpn. Soc. Hortic. Sci., 72, 451-456.

Kim, J.W., Huh, J.E., Kyung, S.H. \& Kyung, K.H. (2004): Antimicrobial activity of alk(en)yl sulfides found in essential oils of garlic and onion. Fd Sci. Biotechnol., 13, 235-239.

Kyung, K. \& LeE, Y. (2001): Antimicrobial activities of sulfur compounds derived from S-alk(en)yl-L-cysteine sulfoxides in Allium and Brassica. Fd Rev. Int., 17, 183-198.

LeE, M.Y., LeE, M.K. \& PARK, I. (2007): Inhibitory effect of onion extract on polyphenol oxidase and enzymatic browning of taro (Colocasia antiquorum var. esculenta). Fd Chem., 105, 528-532.

MA, Y., WANG, Q., Hong, G. \& CANTwell, M. (2010): Reassessment of treatments to retard browning of fresh-cut Russet potato with emphasis on controlled atmospheres and low concentrations of bisulphite. Int. J. Fd Sci. Tech., 45, 1486-1494.

Montero-Calderón, M. \& Cerdas-Araya, M.M. (2009). Fruits and vegetables for the fresh-cut processing industry. -in: Martín-Belloso, O. \& Fortuny, R.S. (Eds): Advances in fresh-cut fruits and vegetables processing., Taylor and Francis, Boca Raton, pp. 185-210.

Montouto-Graña, M., Cabanas-Arias, S., Porto-Fojo, S., VÁzquez-Odériz, M.L. \& Romero-Rodríguez, M.A. (2012): Sensory characteristics and consumer acceptance and purchase intention toward fresh-cut potatoes. $J$. Fd Sci., 77, S40-S46.

Pérez-Gilabert, M. \& García-Carmona, F. (2001): Dimethyl sulfide, a volatile flavor constituent, is a slow-binding inhibitor of tyrosinase. Biochem. Biophys. Res. Commun., 285, 257-261.

Ponce, A.G., Fritz, R., del Valle, C. \& Roura, S.I. (2003): Antimicrobial activity of essential oils on the native microflora of organic Swiss chard. Lebensm. Wiss. Technol., 36, 679-684.

Sgroppo, S., Vergara, L. \& Tenev, M. (2010): Effects of sodium metabisulphite and citric acid on the shelf life of fresh cut sweet potatoes. Span. J. Agric. Res., 8, 686-693.

Sinha, N.K., Guyer, D.E., Gage, D.A. \& LiRA, C.T. (1992): Supercritical carbon dioxide extraction of onion flavors and their analysis by gas chromatography-mass spectrometry. J. Agric. Fd Chem., 40, 842-845.

Steven, F.S., Griffin, M.M. \& SMith, R.H. (1981): Disulphide exchange reactions in the control of enzymic activity. Eur. J. Biochem., 119, 75-78. 